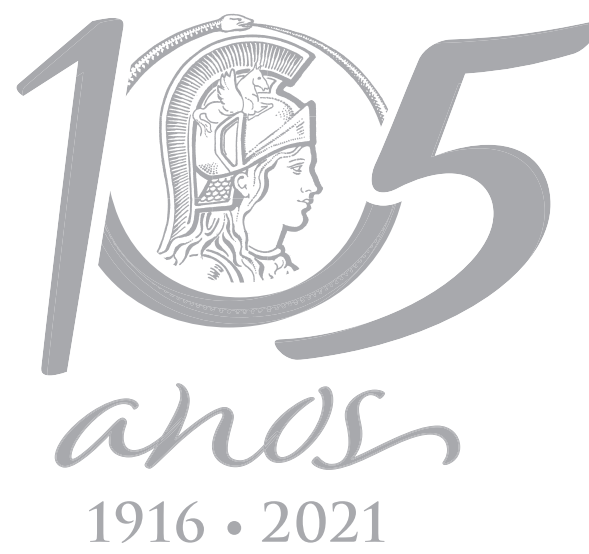

\title{
ECOSYSTEMS
}

\section{Trophic ecology of the Neotropical tolerant fish Corydoras paleatus under the influence of contrasting environmental conditions in a prairie stream}

\author{
ANDREA BERTORA, MARÍA S. FONTANARROSA, FABIÁN GROSMAN, PABLO \\ SANZANO \& JUAN J. ROSSO
}

\begin{abstract}
Worldwide, land use changes and urbanization affect habitat and biota in streams, drastically disrupting environmental conditions and biotic interactions. We evaluated the trophic ecology of the tolerant fish Corydoras paleatus in a prairie stream with contrasting environmental conditions intimately aligned with different nearby land uses. Gut analyses was conducted at three stream reaches with contrasting ecological attributes regarding water quality, habitat structure and riparian condition. A total of 231 guts were analyzed and 15 prey items identified. A significant variation in composition and structure of the dietary assemblage, niche breadth and feeding patterns of C. paleatus under different environmental conditions was observed. Psychodidae prevailed in most deteriorated environmental conditions and Chironomidae, followed by nematodes, in stream reaches where environmental conditions improved. Maximum niche breadth and a larger proportion of generalist individuals were found at the most deteriorated site. Conversely, the proportions of specialized individuals were slightly higher at sites with better ecological conditions. Psychodidae and mineral fragments were positively correlated with the most detrimental conditions, while filamentous algae prevailed where these conditions improved. Overall, good evidence suggesting that trophic ecology of a tolerant species is affected by local environmental conditions in water quality, habitat structure and riparian corridor was observed.
\end{abstract}

Key words: Chironomidae, habitat structure, land use, Psychodidae, riparian condition, water quality.

\section{INTRODUCTION}

Freshwater ecosystems face a major threat derived from the development of human populations in their drainages (Albert et al. 2020), where streams are particularly vulnerable (Walsh et al. 2005). Careless intensive land use practices produce structural and functional changes in streams (Allan 2004). Several aspects of water chemistry, habitat structure, channel morphology, macrophytes coverage, substrate composition and riparian vegetation are drastically affected (Platts 1979, Paul \& Meyer 2001, Walsh et al. 2005, Moss 2008, Arocena et al. 2018, O'Callaghan et al. 2018). Their effects on the ecological integrity of the streams also generate direct and indirect impacts on different aquatic communities, including the composition and structure of fish communities (Karr 1981), but also population aspects, such as trophic ecology (Aranha et al. 1998, Ferreira et al. 2012, Dala-Corte et al. 2016).

Human activities in the landscape may affect diet of fish communities directly, for 
example by removal of the forest canopy that provides allochthonous food (e.g., terrestrial insects and seeds), and indirectly by siltation that causes destruction of microhabitats that act as food deposits and shelters (Melo et al. 2004). Altered environmental conditions favored by land uses practices are also translated into changes in the availability and abundance of fish prey organisms (Karr et al. 1986), such as macroinvertebrates (Crowl et al. 1997, Muotka et al. 1998). On the other hand, where the channel morphology, hydrology and surroundings are preserved, larger food resources from different sources are available (Carvalho \& Uieda 2010, Cruz et al. 2013). The heterogeneity of habitats in these preserved freshwater ecosystems provides diverse substrates with different foraging opportunities and many ways for fish to explore food resources available (Willis et al. 2005, Figueiredo et al. 2013, 2015, Montaña et al. 2015, Ceneviva-Bastos et al. 2017). Overall, the diet can be used as a proxy for the availability of food items in the environment (Winemiller 1989, Wootton 1999) because changes in resource availability are commonly noticed in the stomach contents and trophic behavior of the species (Zeni \& Casatti 2014, Rennella et al. 2019). In consequence, the diet and trophic behavior of the different fish species have being altered by changes of environmental conditions imposed by nearby land uses (Aranha et al. 1998, Grether et al. 2001, Ceneviva-Bastos \& Casatti 2007, Ferreira et al. 2012, Manna et al. 2012, DalaCorte et al. 2016).

Most of the studies addressing changes in trophic ecology of Neotropical stream fishes under different environmental scenarios (Ceneviva-Bastos \& Casatti 2007, Ferreira et al. 2012, Manna et al. 2012, Figueiredo et al. 2013, 2015, Dala-Corte et al. 2016, among many others), were focused on visual predator species (for instance Astyanax paranae, Astyanax taeniatus,
Bryconamericus iheringii, Knodus moenkhausii). Moreover, they were conducted in naturally forested riparian corridors, where the role of woody cover is central to the trophic ecology of fishes by providing allochthonous food resources (Zeni \& Casatti 2014). Comparatively, less attention has been paid to evaluate the trophic ecology of Neotropical nonvisual predator species under contrasting environmental conditions (Tófoli et al. 2013). The peppered catfish Corydoras paleatus is a non-visual, generalist and tolerant Siluriformes species (Bozzetti \& Schulz 2004, Hued \& Bistoni 2005, Chalar et al. 2013) widely distributed in the lower Paraná River basin, coastal rivers from Southern Brazil and Uruguay and Uruguay River basin (Tencatt et al. 2016). Due to its ecological tolerance and widespread distribution, this species would be a good candidate to evaluate the influence of different environmental conditions on the trophic ecology of a nonvisual Neotropical species.

In the Pampa Plain, streams naturally lack a native forested riparian zone, allowing a high irradiance even in their upper reaches (Feijoó \& Lombardo 2007). Currently, the riparian vegetation is largely characterized by herbaceous cover, some shrubs and exotic trees. These streams also present a welldeveloped community of macrophytes with an autochthonous primary production relaying on algal and macrophyte communities and an autotrophic production to respiration rate $(P / R)$ where primary production prevails over respiration processes (Vilches 2005). During the last few decades, drastic changes in land uses have occurred in the Pampa Plain. The main cause of these changes is the advance of the agricultural boundaries (Viglizzo et al. 2001) and the consequent displacement of livestock to marginal lowland areas. This scenario has affected the ecological integrity of regional rivers 
and streams (Gabellone et al. 2005, Feijoó et al. 2012, Rosso \& Fernández Cirelli 2013, Cochero et al. 2016) with strong effects on fish assemblages through changes in abundance and distribution of species (Giorgi et al. 2014, Bertora et al. 2018a, Paracampo et al. 2020). In this context, some Siluriformes are commonly observed in more impacted environments (Rosso \& Quirós 2009, Granitto et al. 2016).

Corydoras paleatus is a typical element of fish communities in freshwater ecosystems of the Pampa Plain (Rosso 2006) found from preserved to altered stream conditions. The diet composition of this species under natural conditions of lotic ecosystems is mainly composed by larvae and adult insects, followed by microcrustaceans, as well as detritus, algae, plant remains and plankton (Fernández et al. 2012, López Cazorla et al. 2003). Unfortunately, little is known about the diet of $C$. paleatus under scenarios with contrasting environmental conditions where water quality, habitat structure and riparian conditions are altered. The variety of resources in the diets of fish species may reflect the functional-trophic integrity of the ecosystems (Neves et al. 2015). Particularly, the evaluation of the feeding habits of fish under the influence of different human impacts on stream environmental conditions represents a key tool for assessing the biotic integrity of these ecosystems (Bonato et al. 2012). In this respect, tolerant species which are commonly found in a wide array of habitats (including the most impacted) are eligible to this end. Indeed, the abundance and distribution of tolerant fish species has been routinely used as bioindicator (Lyons et al. 1996, McCormick et al. 2001). However, minimal attention is being paid to other ecological adjustments in biological traits of these species (Marques et al. 2019), as feeding, growth or reproductive patterns that may be coupled with its tolerant behavior. In this respect, it could be anticipated that detrimental aspects of water quality, habitat structure and riparian conditions of streams may be still important for the trophic ecology of tolerant fishes. Nevertheless, this is rarely addressed.

In this paper, we characterize the diet of the non-visual, tolerant Corydoras paleatus along a prairie stream and explore its feeding ecology in different reaches with contrasting environmental conditions covering aspects of water quality, habitat structure and riparian conditions. We predicted that some aspects of its feeding ecology, as diet composition and structure or feeding patterns, will be related with the variation in the environmental conditions of sampled reaches. As such, they could act as complementary indicators of the ecological integrity of aquatic ecosystems. As water quality, habitat structure and riparian conditions in streams are largely influenced by nearby land uses, we argued about the eventual role of human activities in the surrounding landscape on the trophic ecology of a tolerant fish species.

\section{MATERIALS AND METHODS}

\section{Study area}

The Langueyú stream is located in the Pampa Plain, southeast of Buenos Aires province, Argentina (Figure 1). This system belongs to the Langueyú Basin which has an area of approximately $600 \mathrm{~km}^{2}$. It heads at the Tandilia hills, flowing in southwest to northeast direction. Along its course, it runs through Tandil, Rauch and Ayacucho cities and finally flows into the Atlantic Ocean by means of a man-made channel. The basin is characterized by high agricultural productivity in the rural area and industrial developments, mainly metallurgical and food industries, in urban and surroundings areas. The stream receives pluvial, wastewater and industrial effluents (many have deficient 


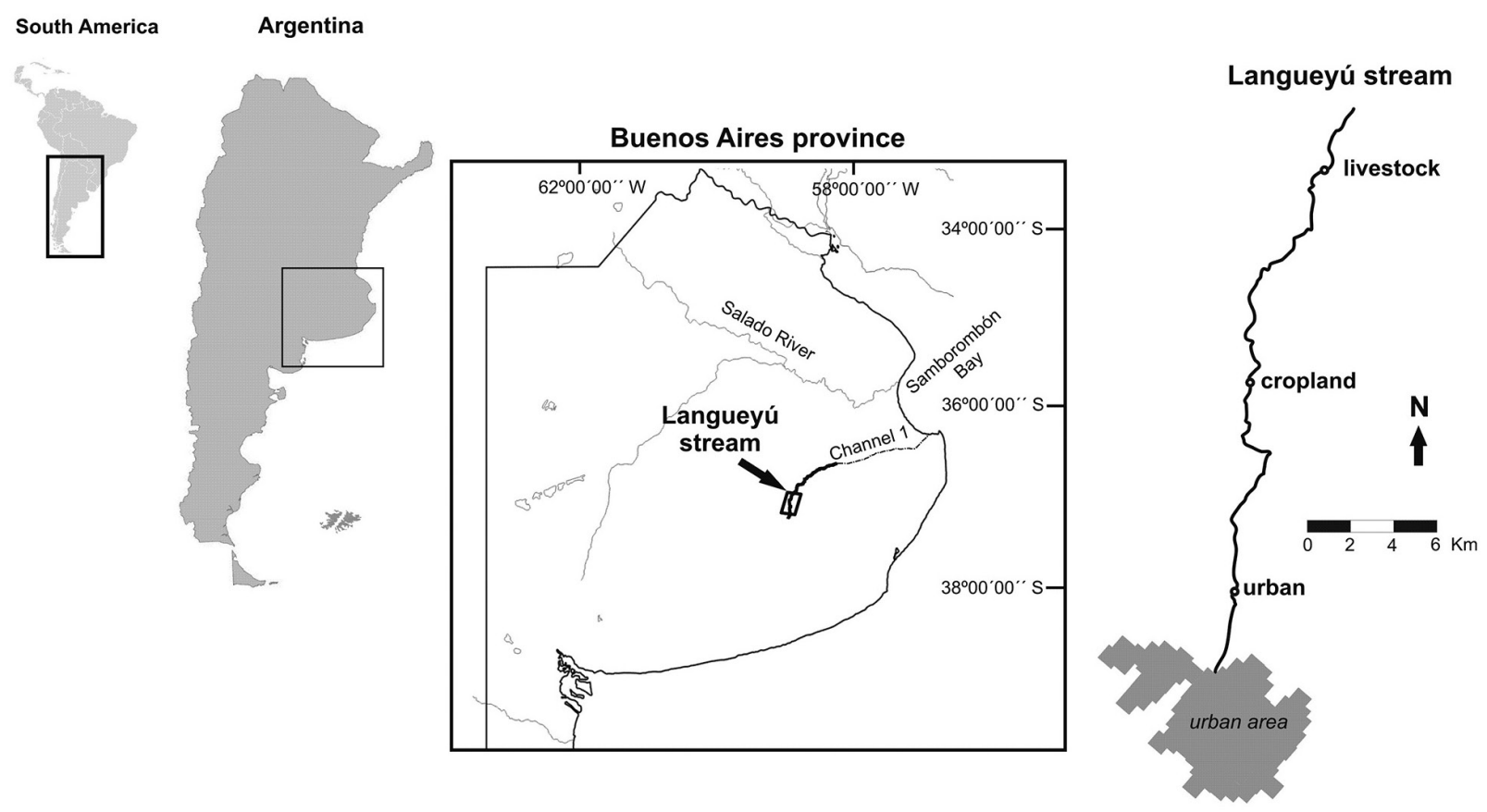

Figure 1. Geographic location of sampled sites of Langueyú stream in the Pampa Plain, Buenos Aires province, Argentina.

treatment, OPDS 2009). Vacuum truck discharges are also common (Banda Noriega \& Díaz 2010, Ruiz de Galarreta et al. 2010, 2013).

The fish community of the Langueyú stream has been recently explored (Bertora et al. $2018 \mathrm{~b}$ ), yielding a total of 16 species. Among the representative species, only Corydoras paleatus was collected in different stream reaches with contrasting environmental conditions imposed by different land uses.

\section{Sample collection}

\section{Sampling sites}

Three reaches of the Langueyú stream (100 meters long) with contrasting environmental conditions were selected. One of these reaches represents a strongly impacted condition by modification of the riparian vegetation given by forestation with planted exotic trees species and by Tandil city and its industrial development through the discharge of pluvial, wastewater and industrial effluents (labeled as urban site $=\mathrm{U}$, $37^{\circ} 16^{\prime} 24^{\prime \prime} \mathrm{S}, 059^{\circ} 07^{\prime} 35^{\prime \prime} \mathrm{W}$ ). Downstream, where waters already show self-depuration signs (Ruiz de Galarreta et al. 2013) and the riparian corridors are covered by native vegetation (lacking woody vegetation), two more reaches were evaluated. These reaches are exposed to cropland (labeled as cropland site = C, 37 $11^{\prime} 15^{\prime \prime}$ $\mathrm{S}, 059^{\circ} 08^{\prime} \mathrm{W}$ ) and livestock (labeled as livestock site $=\mathrm{L}, 37^{\circ} 05^{\prime} 47^{\prime \prime} \mathrm{S}, 059^{\circ} 06^{\prime} 29^{\prime \prime} \mathrm{W}$ ) activities in their surrounding landscapes. Linear distances between sampled sites were $12.2 \mathrm{~km}(\mathrm{U}-\mathrm{C})$ and $13.7 \mathrm{~km}$ (C-L). Croplands in the landscape include intensive crops of soy, wheat and corn extending up to a few meters from the stream banks. In contrast, cattle have unrestricted access to the watercourse. These land use practices have already shown to have effects on the riparian condition, water quality and habitat structure of streams in the Pampa Plain (Rosso \& Fernández Cirelli 2013). Therefore, we explored these 
local environmental conditions as in-stream surrogates of nearby land use practices.

\section{Environmental variables}

Differentenvironmentalvariables were measured to characterize each sampling site, including features of water quality, habitat structure and riparian condition. Water temperature, $\mathrm{pH}$, dissolved oxygen and water conductivity were measured in situ using a multiparametric probe. Water samples were taken at mid-depth and midstream and then processed in the laboratory. Nitrate, ammonium and total suspended solids were quantified according to standard methods (APHA-AWWA-WEF 2012). The characterization of habitat structure and riparian corridor were performed by means of five equidistant transects perpendicular to the stream and covering the entire reach under study (transects at 0, 25, 50, 75 and 100 meters). On each transect, the stream width, water depth and sediments column depth were measured; the latter two in four equidistant points on each transect. In addition, the vegetation cover was quantified determining the relative cover of different forms of macrophytes growth (submerged, emergent and floating) on each transect. The linear distances across each transect that were covered by each type of macrophytes were measured and the proportion of the stream width accounted for each type was calculated (Fletcher et al. 2000). The instream canopy area (expressed as percentage) within each zone delimited by two consecutive transects was visually quantified. The riparian width was measured at both margins of each transect. In the riparian corridor, the proportion of woody cover (trees and shrub) and bank stability (relation between the linear length of banks covered by macrophytes and roots over the total length) were quantified following Rosso \& Fernández Cirelli (2013). For further analyses a site mean of each variable of habitat structure and riparian condition was calculated by averaging the values recorded in the five transects. The only exception was the riparian width, where the minimum value recorded was used in analyses. The rationale behind this is to avoid underestimation of the effect of cattle in riparian development that is likely because animals do not homogeneously disrupt the stream bank along the entire length of stream reaches when accessing the water.

\section{Fish and gut contents}

At each sampling site, three fishing campaigns were conducted during each of three consecutive summers (2016/17; 2017/18; 2018/19). Collection permit was granted by the Ministry of Agroindustry of the Buenos Aires province (Resolution $N^{\circ}$ 409). Fish sampling and handling protocols followed during the course of our surveys were evaluated and approved by the Ethics Comitee of the Facultad de Ciencias Exactas y Naturales of the Universidad Nacional de Mar del Plata (RD-2018-126). Fish captured were euthanized by an overdose in benzocaine solution as suggested by international guidelines (Barker et al. 2002).

specimens of Corydoras paleatus were measured and the standard length was recorded. Then, the specimens were opened by a longitudinal incision in the ventral plane, their guts were removed cutting in the esophagus, fixed in 10\% formalin and preserved in $70 \%$ ethanol.

\section{Laboratory processing}

The repletion level of the guts was measured providing a filling percentage based on the observation of the wall swelling and the amount of content. A combination of occurrence, numerical and gravimetric methodologies 
(Hyslop 1980) was conducted. The analysis was performed using the first third of the gut. Prey items were identified to the lowest taxonomic level under stereomicroscope and optical microscope (Needham \& Needham 1982, Lopretto \& Tell 1995). The number of preys was counted and the presence of semidigested preserved structures of insects (heads, respiratory siphons, wings, eyes) was used to count for additional individuals, adding these counts to the total of each category. Coarse mineral particles (average size $1 \mathrm{~mm}$ ) and vegetal remains were also counted. Then each prey item was weighted (wet biomass in grams) in analytical balance (0.0001g).

\section{Data analysis}

A Principal Component Analysis (PCA) was performed with all the environmental variables to explore spatial ordination of sampled sites. Only data of those sampling dates when fish were actually collected are included $(U=6 ; C=7$; $L=6)$. Environmental data were standardized (to zero mean and unit variance) to perform this analysis. PCA scores were further used to explore empirical relationships between diet and the environmental conditions by means of a spearman correlation coefficient between scores and prey items matrices.

The vacuity index (Molinero \& Flos 1991) was calculated as the proportion of empty guts over the total guts analyzed in each site. The relative contributions of abundance $(\% \mathrm{~N})$ and biomass ( $\% \mathrm{G}$ ) of each prey item were expressed as percentage of the total abundance and biomass of all items. In addition, the frequency of occurrence (Fo, Hyslop 1980) of each prey item was estimated as the number of guts with prey item $x$ in relation to the total guts analyzed. The composition of the dietary assemblage was analyzed through the Index of Relative Importance modified by Hacunda
(1981), an index that includes the percentage contribution of abundance and biomass and frequency of occurrence (in percentage) of different prey items consumed (IRI= (\%N + \%G) * Fo). The trophic behavior under contrasting environmental conditions was characterized using the graphic method proposed by Costello modified by Amundsen et al. (1996), based on the frequency of occurrence and specific abundance (the percentage a prey taxon comprises of all prey items in only those predators in which the actual prey occurs). The niche breadth (Levins 1968) for each specimen was also calculated. Niche breadth values vary from 1 if a species consumes a single type of prey item, to $x$, if a species equitably consumes all prey items. To determine the degree of individual specialization of diet (IS), the mean proportional similarity between individuals and population (PSi) was used (Bolnick et al. 2002). The main advantages of this metric over others are that it estimates specialization for each sample. Therefore, it is not too sensitive to artifacts resulting from the presence of purely monophagous samples, and it makes no assumption about particular distributions of resources (Bolnick et al. 2002). Both matrices of abundance and biomass of prey items consumed were used for this analysis. PSi values varies from values close to 1, indicating individuals generalists (complete overlap between the individual and the population), to near 0 , indicating strong individual specialization. Population's prevalence of individual specialization (IS) was measured by the average of individuals PSi values from different sites (Bolnick et al. 2002). Monte Carlo permutations test was performed to evaluate whether observed PS values differed significantly from a random distribution (999 permutations) of values subsampled from the population. All these analyses were performed using the RInSp package (Zaccarelli et al. 2013). To 
compare the degree of individual specialization from different sites a Kruskal-Wallis test and post-hoc a pairwise comparison by MannWhitney test were performed using PSi values for abundance and biomass prey items.

The distribution of the relative abundance and biomass of prey items was analyzed by the modified Shapiro-Wilks test (Mahibbur \& Govindarajulu 1997). Since the data did not follow a normal distribution, a non-parametric analysis of the variance by Kruskal-Wallis test was performed to test if abundance and biomass of prey items significantly differed between contrasting environmental conditions.

To explore differences in the structure of the diet of $C$. paleatus in different environmental conditions, the non-parametric Permutational Multivariate Analysis of Variance (PERMANOVA, Anderson 2005) was performed on Bray-Curtis similarity matrices of abundance and biomass of prey items. We generated 9,999 permutations to assess the significance of the pseudo $F$ values. Subsequently, the similarity-percentage analysis (SIMPER, Clarke 1993) was used to determine the level of dissimilarity of the diet structure between pairs of sites and the relative contribution of each prey item to discriminate pairs of diets under different environmental conditions.

All statistical analyses were performed with PAST 4.01 (Paleontological Statistics software package for education and data analysis), InfoStat 2019 and RStudio 1.2.5001 packages.

\section{RESULTS}

\section{Environmental conditions}

Mean environmental variables measured at each sampling site are shown in Table I. The stream reach exposed to urban conditions was characterized by a very low concentration of dissolved oxygen and NO3:NH4 ratio. Conversely, water conductivity and total suspended solids were high. The habitat structure was characterized by a larger column of sediments and the absence of macrophytes, whereas the presence of forestation in the riparian corridor generated a larger proportion of woody cover and shade on the stream (Table I, Figure 2). Conversely, livestock-exposed reach was wider, deeper and with higher proportion of sub merged macrophytes. In addition this site also showed a decrease in the riparian vegetation width and banks stability (Table I, Figure 2). Finally, in the stream site exposed to agriculture, water quality was similar to livestock-exposed site, habitat structure was characterized by the presence of macrophytes and riparian vegetation showed mainly herbaceous development, high bank stability and open canopy. In the multivariate ordination of the environmental conditions and sampling sites, the first two components explained $67 \%$ of the total variation. Water conductivity, total suspended solids, woody coverage and sediment depth showed a positive correlation with the first component, while dissolved oxygen, macrophytes, stream width and open canopy were negatively related. On the other hand, $\mathrm{pH}$, bank stability and riparian width were positively correlated with the second principal component. The arrangement of samples sites in the biplot based on its environmental variables discriminated three groups according to different environmental conditions. Samples of the urban site were positioned towards the positive end of the first component, while those of the livestock site grouped at the negative end. Cropland samples were largely confined to a zone surrounding the centroid of the ordination and in the positive zone of the second component (Figure 2). 
Table I. Environmental variables measured to characterize the sampled sites.

\begin{tabular}{|c|c|c|c|c|c|c|c|}
\hline \multirow{2}{*}{ Variable } & \multirow{2}{*}{ Code } & \multicolumn{2}{|c|}{ urban } & \multicolumn{2}{|c|}{ cropland } & \multicolumn{2}{|c|}{ livestock } \\
\hline & & mean & SD & mean & SD & mean & SD \\
\hline $\mathrm{T}\left({ }^{\circ} \mathrm{C}\right)$ & & 23.28 & 3.16 & 21.86 & 3.91 & 23.14 & 3.2 \\
\hline $\mathrm{pH}$ & & 8.31 & 0.3 & 8.89 & 0.59 & 8.71 & 0.46 \\
\hline dissolved oxygen (mg/l) & DO & 1.44 & 1.8 & 9.33 & 4.3 & 11 & 3.25 \\
\hline water conductivity ( $\mu \mathrm{S} / \mathrm{cm})$ & WC & 1167 & 108.98 & 1077.56 & 93.81 & 1049.67 & 98.45 \\
\hline total suspended solids (mg/l) & TSS & 74.79 & 30.83 & 11.92 & 10.75 & 9.54 & 10.81 \\
\hline $\mathrm{NO}_{3}: \mathrm{NH}_{4}$ & & 0.44 & 0.42 & 0.77 & 0.53 & 1.75 & 2.26 \\
\hline macrophytes (\%) & macrop. & 0 & 0 & 0.24 & 0.15 & 0.39 & 0.17 \\
\hline sediment column depth $(\mathrm{cm})$ & sedim. & 4.94 & 2.33 & 2.11 & 1.44 & 1.12 & 0.85 \\
\hline stream width average $(\mathrm{m})$ & width & 5.12 & 0.15 & 7.32 & 0.97 & 9.53 & 2.03 \\
\hline water depth average $(\mathrm{cm})$ & depth & 36.73 & 3.13 & 35.53 & 5.02 & 54.78 & 16.07 \\
\hline riparian width (m) & & 9.24 & 0 & 9.73 & 0.55 & 0 & 0 \\
\hline bank stability (\%) & stability & 0.84 & 0.1 & 0.74 & 0.09 & 0.57 & 0.04 \\
\hline wood cover (\%) & & 0.22 & 0.02 & 0.02 & 0.01 & 0 & 0 \\
\hline open canopy (\%) & & 0.52 & 0.07 & 0.96 & 0.01 & 1 & 0 \\
\hline
\end{tabular}

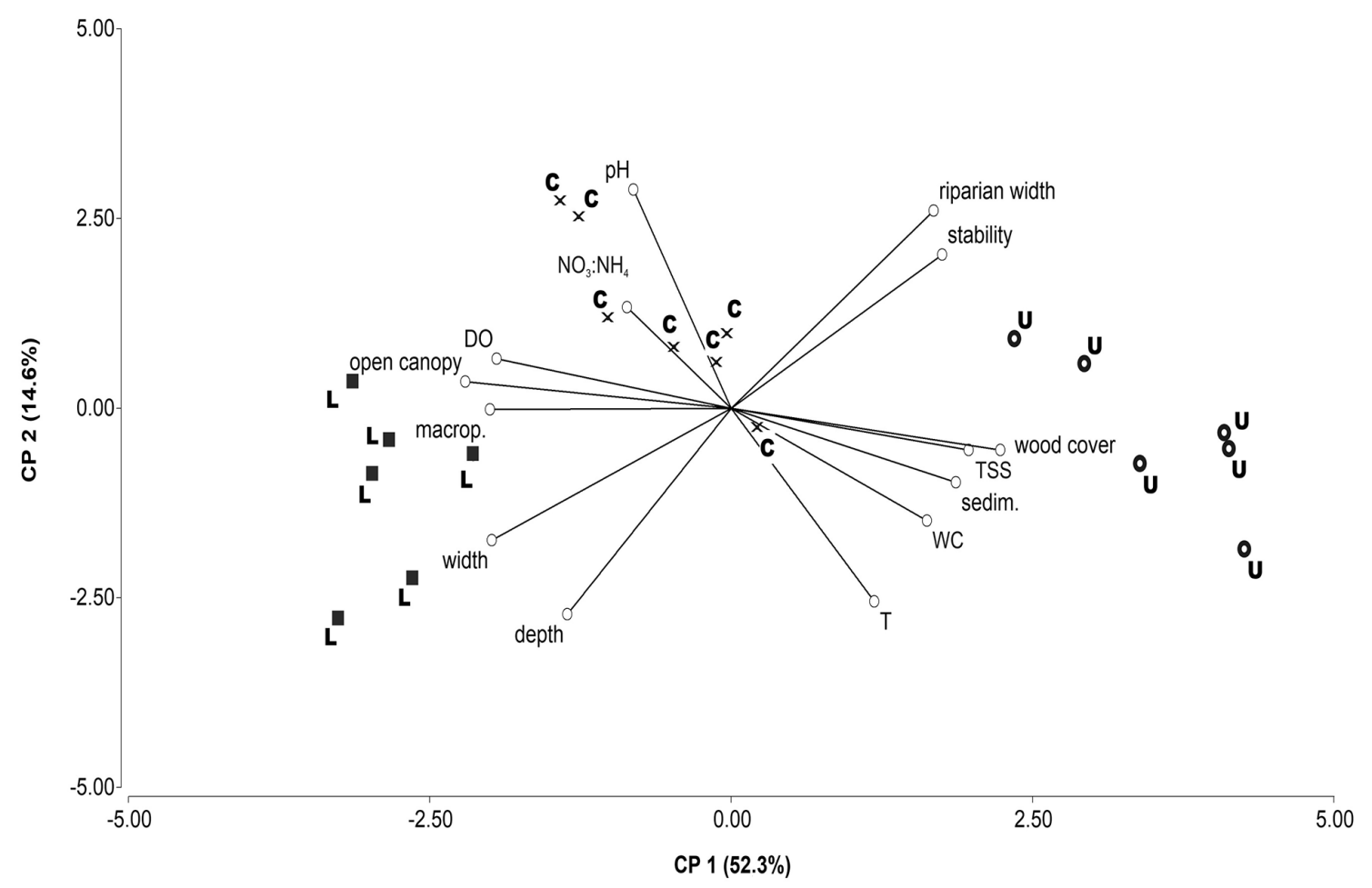

Figure 2. Principal Components Analysis of samples based on environmental condition characterization. Environmental variables code as Table I. $\mathrm{U}=$ urban. $\mathrm{C}=$ cropland. $\mathrm{L}=$ livestock. Percentages of the explained variance are shown on each axis. 


\section{Trophic ecology of Corydoras paleatus}

A total of 231 guts of Corydoras paleatus were analyzed and 175 of these presented identifiable content, while the remaining contained mucus or highly digested material. A minimum of 69 guts were analyzed for each sampling site (Table II). The range of standard lengths in the analyzed specimens was similar between different sites as it was the level of repletion and vacuity indexes (Table II).

A total of 15 prey items were identified in diet of $C$. paleatus under different environmental conditions (Table III). Chironomidae, Muscidae and Nematoda spp. 1 were found in all sampling sites (Table III). Nevertheless some prey items were exclusive of a particular site. For instance, Copepoda Cyclopoida was only identified in the urban site, whereas Tipulidae was restricted to the cropland site. Tardigrada, Nematoda spp. 2, filamentous algae and diatoms were only consumed in the livestock site. Oligochaeta was absent in urban site, and vegetal, mineral fragments and Ceratopogonidae were absent in the livestock site.

In the urban site, the Psychodidae constituted the main prey item, following by Chironomidae, Nematoda spp. 1 and mineral fragments (Figure
3). In contrast, the composition of dietary assemblage in the cropland and livestock sites was largely dominated by Chironomidae and seconded by Nematoda spp. 1. In the cropland site, Psychodidae and other insects were also important. Prey items like filamentous algae, mineral fragments, Chironomidae, Psychodidae and other insects showed significant differences in abundance and biomass between sites (Table III). Moreover, Psychodidae and mineral fragments showed a high, positive and significant correlation with PC1 scores (Table IV), while filamentous algae correlated negatively with PC1 scores. In turn, other insects showed high, positive and significant correlations with PC2 scores, while filamentous algae were also negatively correlated with PC2 scores.

The structure of the diet of $C$. paleatus (including all prey items consumed) showed significant differences among sampling sites with contrasting environmental conditions, considering the abundance and biomass of the prey items ( $p$ seudo $F=16.42, p$ value $=0.0001$ and pseudo $F=13.76, p$ value $=0.0001$, respectively). All the contrasts among pairs of sites showed significant differences in the diet structure, both in abundance (U-C: pseudo $F=17.92, p$ value=

Table II. Standard length of specimens (SL), number of guts analyzed, guts repletion and number of prey items found in diet of $C$. paleatus from the different sampling sites.

\begin{tabular}{|c|c|c|c|c|}
\hline \multicolumn{2}{|c|}{ Variables } & \multirow{2}{*}{$\begin{array}{l}\text { urban } \\
52.04\end{array}$} & \multirow{2}{*}{$\begin{array}{c}\text { cropland } \\
48.56\end{array}$} & \multirow{2}{*}{$\begin{array}{c}\text { livestock } \\
48.88\end{array}$} \\
\hline \multirow{3}{*}{ SL of specimens (mm) } & mean & & & \\
\hline & standard deviation & 5.91 & 13.01 & 10.47 \\
\hline & range & $29-71$ & $16-75$ & $25-70$ \\
\hline \multirow{2}{*}{ Guts analyzed (n) } & total & 69 & 78 & 84 \\
\hline & with identifiable content & 50 & 58 & 67 \\
\hline Repletion level (\%) & mean & 44.50 & 42.41 & 41.94 \\
\hline Vacuity index (\%) & total & 27.54 & 25.64 & 20.24 \\
\hline Number of prey items & total & 9 & 10 & 10 \\
\hline
\end{tabular}


0.0001; U-L: pseudo $F=27.19, p$ value $=0.0001 ; C-L$ : pseudo $\mathrm{F}=6.12, p$ value $=0.0006)$ and in biomass of the prey items ( $\mathrm{U}-\mathrm{C}$ : pseudo $\mathrm{F}=13.28, p$ value $=$ 0.0001; U-L: pseudo $F=22.87, p$ value $=0.0001 ; C-L$ : pseudo $F=6.15, p$ value $=0.0002$ ).

The dissimilarity of the diet structure between pairs of sites obtained by SIMPER was high (in all cases greater than 70\%), being the differences maximum between urban and livestock sites (Table V). Psychodidae, Chironomidae and the Nematoda spp. 1 were the items that contributed most to explain the differences between the study sites, accounting for more than $61 \%$ of the differences (Table V).

In the sampled site exposed to urban conditions, more than $70 \%$ of the individuals consumed Psychodidae and Chironomidae (Figure 4). In addition, a tendency to ingest several preys in low abundance was observed. On the contrary, in cropland and livestockexposed sites, a dominance of Chironomidae and the ingestion of many prey in low frequency and abundance was observed. As environmental conditions improved, some specimens (less than $10 \%)$ preferentially consumed certain preys, as Tipulidae in cropland-exposed site or diatoms and Tardigrada in livestock-exposed site.

Accordingly with the tendencies observed, niche breadth was significantly different between sites $(H=19.24 ; p$ value $<0.0001)$ being maximum in the most detrimental conditions of the urban-exposed reach ( $U$ mean $=1.804 ; S D=$ 0.553; $\mathrm{C}$ mean $=1.522 ; \mathrm{SD}=0.5 ; \mathrm{L}$ mean $=1.304 ; \mathrm{SD}=$ $0.367)$.

A larger proportion of generalist individuals was observed in the urban-exposed site (IS

Table III. Taxonomic, percentage contribution of the abundance (\%N, mean) and biomass (\%G, mean), and frequency of occurrence ( $\mathrm{Fo}$ ) of each prey item in diet of $C$. paleatus under different environmental conditions ( $\mathrm{U}=$ urban, $\mathrm{C}=$ cropland, $\mathrm{L}=$ livestock). Bold values highlight the most important prey item for each stream site. Significance of the differences in prey items between sites by Kruskal-Wallis test (only $p$ values $<0.05$ ) is shown.

\begin{tabular}{|c|c|c|c|c|c|c|c|c|c|c|c|}
\hline \multirow{2}{*}{ Prey items } & \multicolumn{4}{|c|}{$\% \mathbf{N}$} & \multicolumn{4}{|c|}{$\% \mathbf{G}$} & \multicolumn{3}{|c|}{ Fo } \\
\hline & $\mathbf{U}$ & $\mathrm{C}$ & $\mathbf{L}$ & $p$ value & $\mathbf{U}$ & C & $\mathbf{L}$ & $p$ value & $\mathbf{U}$ & C & $\mathbf{L}$ \\
\hline Diatoms & & & 0.96 & & & & 0.06 & & & & 0.03 \\
\hline Filamentous algae & & & 4.52 & $<0.001$ & & & 0.001 & $<0.001$ & & & 0.02 \\
\hline Vegetal remains & 0.86 & 1.97 & & & 0.10 & 0.39 & & & 0.06 & 0.07 & \\
\hline Nematoda spp. 1 & 12.23 & 17.76 & 16.44 & & 0.77 & 3.52 & 5.71 & & 0.38 & 0.31 & 0.37 \\
\hline Nematoda spp. 2 & & & 3.56 & & & & 2.27 & & & & 0.18 \\
\hline Oligochaeta & & 0.16 & 0.14 & & & 6.19 & 0.17 & & & 0.02 & 0.02 \\
\hline Tardigrada & & & 2.60 & & & & 2.04 & & & & 0.09 \\
\hline Copepoda Cyclopoida & 0.29 & & & & 0.02 & & & & 0.02 & & \\
\hline Ceratopogonidae & 0.58 & 0.16 & & & 0.08 & 0.05 & & & 0.06 & 0.02 & \\
\hline Chironomidae & 23.17 & 62.99 & 70.14 & 0.007 & 10.62 & 62.58 & 86.97 & 0.043 & 0.72 & 0.78 & 0.58 \\
\hline Psychodidae & 56.55 & 10.20 & 0.14 & $<0.001$ & 87.78 & 5.46 & 0.06 & $<0.001$ & 0.8 & 0.36 & 0.02 \\
\hline Tipulidae & & 0.33 & & & & 0.68 & & & & 0.04 & \\
\hline Muscidae & 0.14 & 0.49 & 0.14 & & 0.02 & 1.39 & 0.04 & & 0.02 & 0.05 & 0.02 \\
\hline Others insects & 1.15 & 4.44 & 1.37 & 0.002 & 0.18 & 19.39 & 0.85 & 0.001 & 0.12 & 0.28 & 0.06 \\
\hline Minerals fragments & 5.04 & 1.48 & & $<0.001$ & 0.42 & 0.36 & & $<0.001$ & 0.28 & 0.05 & \\
\hline
\end{tabular}


abundance: 0.569 +/- 0.202, Monte Carlo p value $=0.001$; IS biomass: $0.537+/-0.343$, Monte Carlo $p$ value $=0.001)$. In turn, the proportions of specialized individuals in cropland (IS abundance: $0.497+/-0.268$, Monte Carlo $p$ value= 0.001; IS biomass: $0.458+/-0.249$, Monte Carlo $p$ value $=0.001)$ and livestock-exposed sites (IS abundance: $0.439+/-0.303$, Monte Carlo $p$ value $=0.001$; IS biomass: $0.487+/-0.398$, Monte Carlo $p$ value $=0.001$ ) were slightly higher. Albeit the differences in the degree of specialization between the three sites were not significant (abundance $p$ value $=0.205$, biomass $p$ value $=$ $0.103)$, the individual specialization in specimens of livestock site was significant higher than urban site (abundance $p$ value $=0.044$ ).
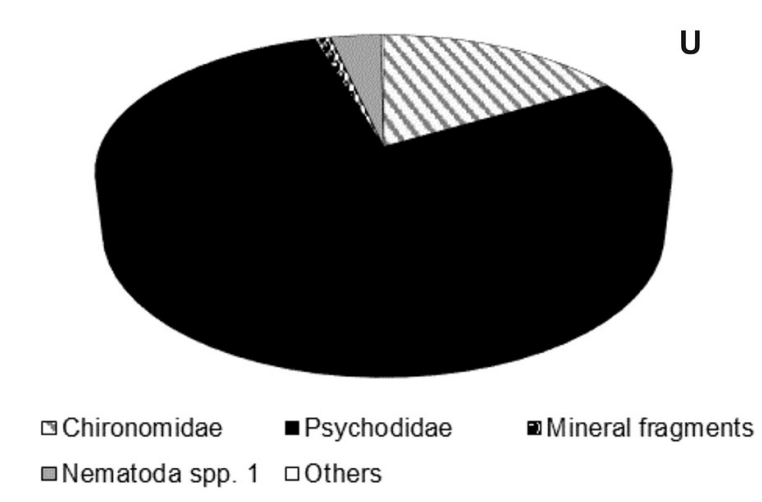

\section{DISCUSSION}

A significant variation in composition and structure of the dietary assemblage, niche breadth and feeding patterns of $C$. paleatus under different environmental conditions of a prairie stream was observed. Overall, the diet of C. paleatus was mostly composed by insects (mainly Chironomidae and Psychodidae), with a lesser relevance of Nematoda, filamentous algae and mineral fragments. Similar results were observed in the diet of C. paleatus from other Neotropical ecosystems (Mills \& Vevers 1989, Delariva et al. 2013) and in the Pampa Plain (López Cazorla et al. 2003, Fernández et al. 2012). These results roughly characterize this species as insectivore irrespective of the environmental conditions and the geographic location of its populations. Indeed, aquatic insects are the
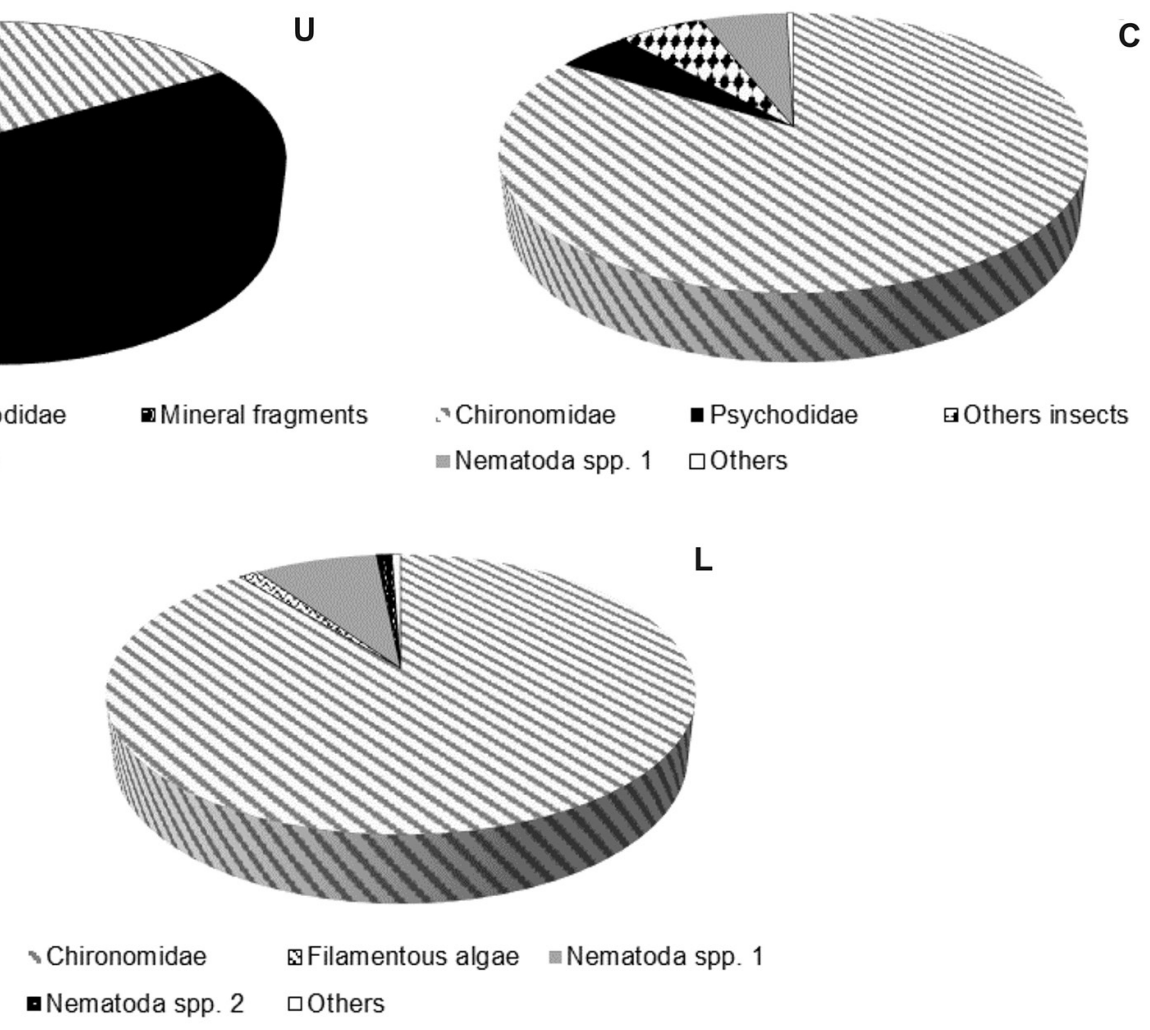

Figure 3 - Percentage contribution of the relative importance index of each prey item in C. paleatus diet under different land uses ( $\mathrm{U}=$ urban, $\mathrm{C}=$ cropland, $\mathrm{L}=$ livestock). 
predominant item in fish diet of Neotropical streams (Winemiller et al. 2008), probably related to the great abundance of this resource in streams (Uieda \& Motta 2007).

C. paleatus consumed 15 different categories but only Chironomidae, Muscidae and Nematoda spp. 1 were found in all reaches. Nevertheless, the frequency of occurrence of Muscidae was low whereas Chironomidae and Nematoda spp. 1 were frequent preys. Accordingly, Chironomidae and Nematoda spp. 1 were among the items that contributed most to discriminate the diet under different environmental conditions. Chironomidae was the main item in the cropland and livestockexposed reaches and was surpassed only by Psychodidae insects in the urban-exposed reach. Chironomidae are the most abundant aquatic insect resource in Neotropical streams (Uieda \& Motta 2007) and are commonly recognized by its tolerance to environmental degradation (Pedersen \& Perkins 1986, Lammert \& Allan 1999). However, Chironomidae is a speciesrich family with a wide spectrum of ecological adaptations. Some chironomids are organisms with intermediate tolerance (Barbour et al. 1999, tolerance 6). This would partially explain the lower contribution of this item to the diet of $C$. paleatus in the urban-exposed reach, finding more suitable environmental conditions in the other two stream reaches. Nematoda are able to inhabiting divergent ecological contexts. Free living nematodes are ubiquitous and may be present in all types of limnetic habitats including harsh conditions (high temperature, acidic, anoxic) that exclude many other meiobenthic invertebrates (Abebe et al. 2008).

Conversely to these common items, the occurrence of other preytaxa was more restricted. The Psychodidae was also an important prey

Table IV. Spearman correlation coefficients between abundance and biomass of prey items and PC scores. Bold numbers highlight statistically significant relationships ( $p$ value $\leq 0.05$ ).

\begin{tabular}{|c|c|c|c|c|c|c|c|c|}
\hline \multirow{3}{*}{ Prey item } & \multicolumn{4}{|c|}{ Abundance } & \multicolumn{4}{|c|}{ Biomass } \\
\hline & \multicolumn{2}{|c|}{ - PC1 scores } & \multicolumn{2}{|c|}{ - PC2 scores } & \multicolumn{2}{|c|}{ - PC1 scores } & \multicolumn{2}{|c|}{ - PC2 scores } \\
\hline & rho & $P$ & rho & $p$ & rho & $p$ & rho & $p$ \\
\hline Diatoms & -0.3 & 0.21 & -0.26 & 0.29 & -0.3 & 0.21 & -0.26 & 0.29 \\
\hline Filamentous algae & -0.58 & 0.01 & -0.46 & 0.05 & -0.58 & 0.01 & -0.46 & 0.05 \\
\hline Vegetal remains & 0.24 & 0.32 & 0.4 & 0.09 & 0.21 & 0.38 & 0.44 & 0.06 \\
\hline Nematoda spp. 1 & -0.09 & 0.73 & -0.27 & 0.27 & 0.02 & 0.93 & -0.19 & 0.44 \\
\hline Nematoda spp. 2 & -0.26 & 0.29 & -0.09 & 0.73 & -0.26 & 0.29 & -0.09 & 0.73 \\
\hline Oligochaeta & -0.08 & 0.75 & -0.06 & 0.81 & -0.08 & 0.75 & -0.06 & 0.81 \\
\hline Tardigrada & -0.3 & 0.21 & -0.26 & 0.29 & -0.3 & 0.21 & -0.26 & 0.29 \\
\hline Copepoda Cyclopoida & 0.17 & 0.48 & 0.22 & 0.38 & 0.17 & 0.48 & 0.22 & 0.38 \\
\hline Ceratopogonidae & 0.19 & 0.44 & 0.39 & 0.10 & 0.19 & 0.44 & 0.39 & 0.10 \\
\hline Chironomidae & 0.15 & 0.55 & 0 & $>0.99$ & -0.19 & 0.45 & 0.02 & 0.94 \\
\hline Psychodidae & 0.58 & 0.01 & 0.33 & 0.17 & 0.54 & 0.02 & 0.36 & 0.13 \\
\hline Tipulidae & -0.13 & 0.60 & 0.39 & 0.10 & -0.13 & 0.60 & 0.39 & 0.10 \\
\hline Muscidae & -0.19 & 0.43 & 0.21 & 0.39 & -0.14 & 0.57 & 0.28 & 0.24 \\
\hline Other insects & -0.04 & 0.86 & 0.31 & 0.20 & -0.01 & 0.98 & 0.46 & 0.05 \\
\hline Mineral fragments & 0.66 & 0.002 & -0.06 & 0.82 & 0.7 & 0.001 & -0.1 & 0.68 \\
\hline
\end{tabular}


item contributing to discriminate the diet of C. paleatus under different environmental conditions. It dominated the diet in the urbanexposed reach being strongly related with the prevalent modified and detrimental conditions of this site (high water conductivity, total suspended solids, woody cover and sediment depth). The importance of the Psychoidae under these conditions could be associated to the high tolerance of these organisms (Barbour et al. 1999, tolerance 10), that have been associated with urban reaches in streams with presence of household wastewater (Couceiro et al. 2007, Martins et al. 2017). Psychodidae larvae develop in diverse microhabitats that range from still or running freshwater or wastewater to the moist soil at the bases of trees, rotten tree trunks and domestic microhabitats such as the drains of bathrooms and kitchens (Young \& Duncan 1994). Young \& Duncan (1994) also reported that adults tend to rest in protected and relatively humid microhabitats, such as in tree holes and the undersides of leaves. All these microhabitats were widely available for Psychodidae in the urban-exposed reach, favored by the proximity to the human settlements and the forested riparian corridor of this site. Altogether, this evidence strongly suggest a causal link between urban development, modified forested riparian corridor and the presence of Psychodidae in the diet of $C$. paleatus of the Langueyú stream.

Inert material in gut analysis is many often attributed to accidental ingestion during feeding and its contribution to the total content of diet is poor. In our study, the mineral fragments were a very typical component of the diet of the urbanexposed reach whereas only a few specimens of other reach also consumed a large proportion of this material. In fact, mineral fragments showed, together with Psychodidae, a high, positive and significant relationship with the detrimental environmental conditions highlighted by the first axis of the PCA. As a metallurgical factory is established upstream of the urban-exposed reach (Banda Noriega \& Díaz 2010, Lan 2017), its contribution to the mineral fragments found in C. paleatus should be considered. Similarly, two species of Astyanax showed a higher consumption of mineral sediments in urban and industrial sites of Tarumã stream basin, in central western Brazil (de Souza \& Lima-Junior 2013). The low nutritional value and digestibility

Table V. Average dissimilarity and percentage contribution of each prey item to discriminate the diet between pairs of sites. Only prey items with a contribution $>5 \%$ were included.

\begin{tabular}{|c|c|c|c|c|c|c|}
\hline \multirow{2}{*}{ Prey items } & \multicolumn{2}{|c|}{ urban - cropland } & \multicolumn{2}{|c|}{ urban - livestock } & \multicolumn{2}{|c|}{ cropland - livestock } \\
\hline & abundance & biomass & abundance & biomass & abundance & biomass \\
\hline Filamentous algae & & & 7.10 & 7.35 & 8.48 & 8.61 \\
\hline Nematoda spp. 1 & 11.85 & 8.68 & 16.46 & 14.84 & 21.21 & 18.4 \\
\hline Tardigrada & & & & & 5.54 & 5.66 \\
\hline Chironomidae & 30.06 & 31.88 & 26.55 & 29.25 & 33.37 & 34.24 \\
\hline Psychodidae & 32.98 & 32.27 & 30.54 & 29.65 & 8.83 & 9.13 \\
\hline Other insects & 10.37 & 14.34 & & & 10.12 & 13.32 \\
\hline Mineral fragments & 7.73 & 5.90 & 5.64 & & & \\
\hline average dissimilarity & 72.78 & 72.82 & 83.92 & 82.27 & 70.27 & 70.2 \\
\hline
\end{tabular}



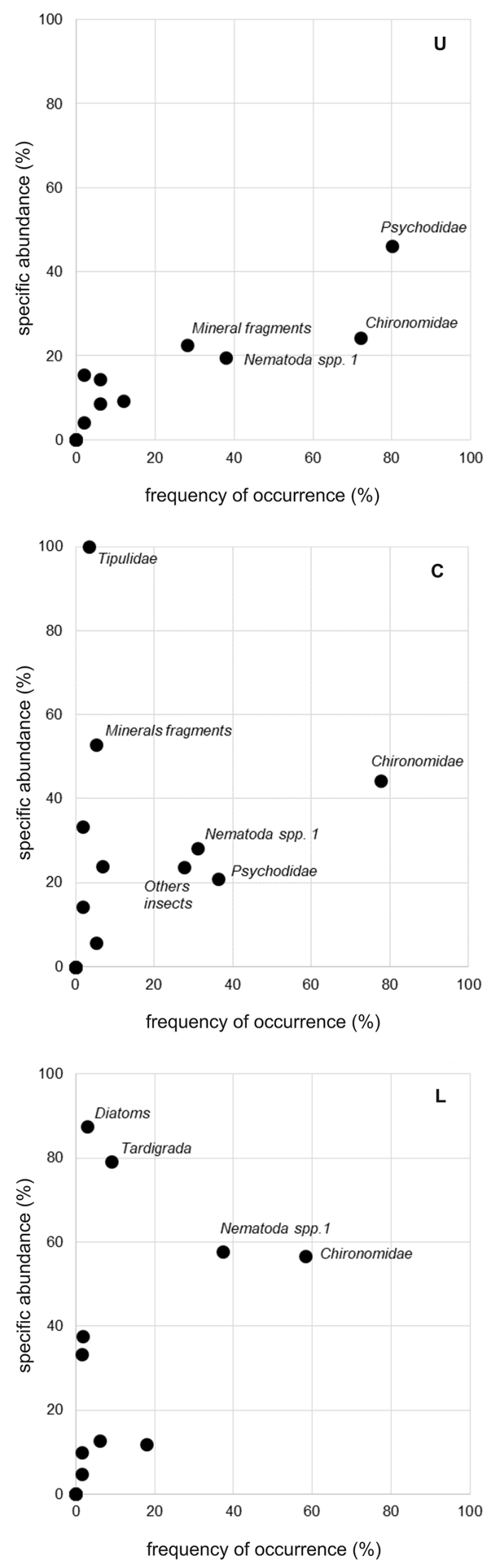

Figure 4. Costello-Amundsen graphs to different sampled sites ( $\mathrm{U}=$ urban, $\mathrm{C}=$ cropland, $\mathrm{L}=$ livestock).

of mineral fragments in relation to other items (Bowen 1983), allow postulating that the increase in consumption of this item is due to its higher availability compared to other items (Peressin et al. 2018).

Some items were exclusively consumed by C. paleatus at particular reaches with particular environmental conditions. For instance, some individuals of the cropland-exposed reach preferentially consumed Tipulidae, which were exclusively found in this site. Tipulids are considered medium tolerance (Alba-Tercedor \& Sanchez Ortega 1988, tolerance 5) and mediumlow tolerance to perturbation (Barbour et al. 1999, tolerance 3) organisms. Hence, its presence in the urban-exposed reach would be hampered. On the other hand, algae (both filamentous and diatoms) and Tardigrada were only consumed by c. paleatus inhabiting the stream reach exposed to cattle impact. Moreover, some specimens preferentially consumed diatoms and Tardigrada. With naturally lacking woody coverage in the riparian corridor, primary productivity would be enhanced in this reach and large amount of colonies of filamentous algae and submerged macrophytes may develop. Open canopy alone may not be enough to explain the preferred presence of algae in the diet of $C$. paleatus under these conditions. The cropland-exposed reach was also almost devoid of any canopy cover but the occurrence of these primary producers in the diet of $C$. paleatus was not recorded. Under cattle impact, asides of the open canopy, the stream width was the largest, increasing the surface area of water exposed to sunlight. This situation together with larger concentrations of dissolved oxygen and NO3:NH4 ratio would favor the development of larger colonies of algae and diatoms which were consumed by $C$. 
paleatus. Indeed, livestock can increase nutrient concentration because animals tend to deposit more excreta in lounging areas near shade and water, especially when access to the streams is unrestricted (Vidon et al. 2008). In our study, the filamentous algae showed a close relationship with the environmental conditions prevailing in the livestock-exposed reach (higher DO, stream width, and open canopy). Algae and macrophytes mats, in turn, could be the source for Tardigrada. Freshwater tardigrades are animals commonly found to crawl on the surface of aquatic plants or algal mats (Nelson \& Marley 2000). Dominance of prey taxa related with primary productivity of streams is not always a natural scenario. Algae and macrophytes often represent a large proportion of fish diet in degraded forested streams (Bojsen 2005, Wootton 2012, DalaCorte et al. 2016) where riparian forest is a natural element of the landscape. For instance, increased consumption of filamentous algae was observed in the diet of Astyanax zonatus (Bojsen 2005) and B. iheringii (Dala-Corte et al. 2016) in riparian-degraded streams of forested headwaters. Conversely, in Pampean streams, with native herbaceous cover in the riparian corridor, C. paleatus showed a high frequency of algae and vegetal remains in his diet (Fernández et al. 2012).

C. paleatus is a species with a high degree of dietary plasticity, being able to take advantage of a given food source at different times or places (Gerking 1994, Abelha et al. 2001). In our study, the niche breadth of C. paleatus was wider at the most impacted conditions. It has been long recognized that the niche breadth increases as the availability of resources decreases (Pianka 1981). A review in Neotropical streams detected a consistent pattern of changes in the feeding niche breadth of fish species caused by alterations in the resource availability (Uieda \& Motta 2007). Although, the availability of resources was not measured in this study, it could be assumed that the hostile environmental conditions of the urban-exposed reach would preclude the development of some intolerant taxa. Environmental conditions of the Langueyú stream could also have affected the trophic behavior of C. paleatus. Generalization of feeding habit is frequently attributed to stream fish (Lowe-McConnell 1987) but Melo et al. (2004) demonstrated that the fish community of Neotropical streams may be much more specialized in terms of feeding than currently assumed. Specialists are common when there is a wide range of resources and these are renewable but become vulnerable when resources are scarce or are not maintained (Roughgarden 1974). In our study, a larger proportion of generalist individuals were observed in the most impacted reach and the specialized trophic behavior was slightly higher in better environmental conditions. The change of trophic behavior from generalist to specialist following the improvement of the environmental condition was also observed in the visualoriented Bryconamericus iheringii in streams of the Tibagi river basin, state of Paraná (Brazil) (Oricolli \& Bennemann 2006). These results suggest that the adjustment of trophic behavior in fishes regarding the ecological conditions would not be related with their visual traits. This "convergent" behavior could be related to particular aspects of the environmental conditions at particular reaches, influencing the availability and abundance of different prey items. The multivariate ordination showed that besides water quality aspects, habitat and riparian variables were also significantly related with the most important prey items. This strongly suggests that the role of local lateral process imposed by contrasting land uses (a component of the metaestructure sensu Poole 2002) and their effects on in-stream water 
quality, habitat structure and riparian structure are still important and may be relevant for the trophic ecology of fishes.

As fish commonly feed on the most abundant and frequent resources of the environment (Cetra et al. 2011, Ferreira-Rezende et al. 2011) it may be assumed that fish diet is a proxy of the availability and abundance of food items found in the environment (Allan \& Castillo 2007). Accordingly, feeding patterns can be altered by differences in food availability and abundance as a result of the environmental changes, as those induced by altered conditions of water quality and habitat structure. Studies about feeding ecology of fish in Neotropical streams indicate that diet can be modified by environmental changes derived from anthropic factors (Abelha et al. 2001, Uieda \& Motta 2007). In this study, we detected good evidence suggesting that trophic ecology of C. paleatus are affected by contrasting environmental conditions in water quality, habitat structure and riparian corridor. As several aspects of in-stream and riparian conditions are strongly modified by nearby land uses, the role of human activities in the surrounding landscape on the trophic ecology of C. paleatus should not be completely ruled out. For populations of C. paleatus living in deteriorated conditions as those encountered in the most impacted reach of the Langueyú stream, marked local adjustments of their feeding habits are expected. In this respect, feeding habits of this tolerant species could be informative for monitoring programs. Indeed, trophic ecology of fishes affected by humanmodified environments has been highlighted as a key tool for assessing the biotic integrity of these streams (Bonato et al. 2012).

\section{Acknowledgments}

Andrea Bertora would like to acknowledge the financial support of doctoral fellowship of the Comision de
Investigaciones Científicas de la Provincia de Buenos Aires (CIC) and the Consejo Nacional de Investigaciones Científicas y Técnicas (CONICET). The authors thank the owners and managers of the study sites for allowing access, and the CONICET for the financial support.

\section{REFERENCES}

ABEBE E, DECRAEMER W \& DE LEY P. 2008. Global diversity of nematodes (Nematoda) in freshwater. In: Balian EV, Lèvêque C, Segers H \& Martens K (Eds), Freshwater Animal Diversity Assessment, Dordrecht: Springer, $p$. 67-78.

ABELHA MCF, AGOSTINHO AA \& GOULART E. 2001. Plasticidade trófica em peixes de água doce. Acta Sci 23: 425-434.

ALBA-TERCEDOR I \& SÁNCHEZ-ORTEGA A. 1988. Un método rápido y simple para evaluar la calidad biológica de las aguas corrientes basado en el de Hellawell (1978). Limnetica 4: 1-56.

ALBERT JS, DESTOUNI G, DUKE-SYLVESTER SM, MAGURRAN AE, OBERDORFF T, REIS RE, WINEMILLER KO \& RIPPLE WJ. 2020. Scientists' warning to humanity on the freshwater biodiversity crisis. Ambio: 1-10.

ALLAN JD. 2004. Landscapes and riverscapes: the influence of land use on stream ecosystems. Annu Rev Ecol Evol Syst 35: 257-284.

ALLAN JD \& CASTILLO MM. 2007. Stream Ecology. Structure and function of running waters. Dordrecht: Springer, 444 p.

AMUNDSEN P, GABLER H \& STALDVIK F. 1996. A new approach to graphical analysis of feeding strategy from stomach contents data modification of the Costello (1990) method. J Fish Biol 48: 607-614.

ANDERSON MJ. 2005. PERMANOVA: a FORTRAN computer program for permutational multivariate analysis of variance. New Zealand: University of Auckland, $24 \mathrm{p}$.

APHA, AWWA \& WEF. 2012. Standard Methods for examination of water and wastewater, $22^{\text {nd }}$ ed., Washington: American Public Health Association, 1360 p.

ARANHA JMR, TAKEUTI DF \& YOSHIMURA TM. 1998. Habitat use and food partitioning of the fishes in a coastal stream of Atlantic Forest, Brazil. Rev Biol Trop 46: 951-959.

AROCENA R, CHALAR G \& PACHECO JP. 2018. Agriculture and elevation are the main factors for Pampasic stream habitat and water quality. Environ Monit Assess: 190-254. 
BANDA NORIEGA R \& DÍAZ AA. 2010. Estimación de Cargas Contaminantes del Arroyo Langueyú. Tandil. Buenos Aires. Ciencia 5: 157-171.

BARBOUR MT, GERRITSEN J, SNYDER BD \& STRIBLING JB. 1999. Rapid bioassessment protocols for use in streams and wadeable rivers: periphyton, benthic macroinvertebrates and fish. Washington: US Environmental Protection Agency, $339 \mathrm{p}$.

BARKER D, ALLAN GL, ROWLAND SJ \& PICKLES JM. 2002. A Guide to Acceptable Procedures and Practices for Aquaculture and Fisheries Research. New South Wales: NSW Fisher, $73 \mathrm{p}$.

BERTORA A, GROSMAN F, SANZANO P \& ROSSO JJ. 2018a. Composición y estructura de los ensambles de peces en un arroyo pampeano con uso de suelo contrastante. Rev del Mus Argentino Ciencias Nat n s 20: 11-22.

BERTORA A, GROSMAN F, SANZANO P \& ROSSO JJ. 2018b. Fish fauna from the Langueyú basin, Argentina: a prairie stream in a heavily modified landscape. Check List 14: 461-470.

BOJSEN BH. 2005. Diet and condition of three fish species (Characidae) of the Andean foothills in relation to deforestation. Environ Biol Fishes 73: 61-73.

BONATO KO, DELARIVA RL \& SILVA JCD. 2012. Diet and trophic guilds of fish assemblages in two streams with different anthropic impacts in the northwest of Paraná, Brazil. Zoologia (Curitiba) 29: 27-38.

BOLNICK DI, YANG LH, FORDYCE JA, DAVIS JM \& SVANBÄCK R. 2002. Measuring individual-level resource specialization. Ecology 83: 2936-2941.

BOWEN SH. 1983. Detritivory in neotropical fish communities. Environ Biol Fishes 9: 137-144.

BOZZETTI M \& SCHULZ UH. 2004. An index of biotic integrity based on fish assemblages for subtropical streams in southern Brazil. Hydrobiologia 529: 133-144.

CARVALHO EM \& UIEDA VS. 2010. Input of litter in deforested and forested areas of a tropical headstream. Brazilian J Biol 70: 283-288.

CENEVIVA-BASTOS M \& CASATTI L. 2007. Oportunismo alimentar de Knodus moenkhausii (Teleostei, Characidae): uma espécie abundante em riachos do noroeste do Estado de São Paulo, Brasil. Iheringia Série Zool 97: 7-15.

CENEVIVA-BASTOS M, MONTAÑA CG, SCHALK CM, CAMARGO PB \& CASATTI L. 2017. Responses of aquatic food webs to the addition of structural complexity and basal resource diversity in degraded Neotropical streams. Aust Ecol 42: 908-919.

CETRA M, RODRIGUES-RONDINELI G \& PEREIRA-SOUZA U. 2011. Compartilhamento de recursos por duas espécies de peixes nectobentônicas de riachos na bacia do rio Cachoeira (BA). Biota Neotrop 11: 87-95.

CHALAR G, DELBENE L, GONZÁLEZ-BERGONZONI I \& AROCENA R. 2013. Fish assemblage changes along a trophic gradient induced by agricultural activities (Santa Lucía, Uruguay). Ecol Indic 24: 582-588.

CLARKE KR. 1993. Non-parametric multivariate analyses of changes in community structure. Aust J Ecol 18: 117-143.

COCHERO J, CORTELEZZI A, TARDA AS \& GÓMEZ N. 2016. An index to evaluate the fluvial habitat degradation in lowland urban streams. Ecol Indic 71: 134-144.

COUCEIRO SR, HAMADA N, LUZ SL, FORSBERG BR \& PIMENTEL TP. 2007. Deforestation and sewage effects on aquatic macroinvertebrates in urban streams in Manaus, Amazonas, Brazil. Hydrobiologia 575: 271-284.

CROWL TA, TOWNSEND CR, BOUWES N \& THOMAS H. 1997. Scales and causes of patchiness in stream invertebrate assemblages: top-down predator effects? J North Am Benthol Soc 16: 277-285.

CRUZ BB, MIRANDA LE \& CETRA M. 2013. Links between riparian land cover, in stream environment and fish assemblages in headwater streams of south eastern Brazil. Ecol Freshw Fish 22: 607-616.

DALA-CORTE RB, BECKER FG \& MELO AS. 2016. Riparian integrity affects diet and intestinal length of a generalist fish species. Mar Freshw Res 68: 1272-1281.

DE SOUZA RG \& LIMA-JUNIOR SE. 2013. Influence of environmental quality on the diet of Astyanax in a microbasin of central western Brazil. Acta Sci Biol Sci 35: 179-184.

DELARIVA RL, HAHN NS \& KASHIWAQUI EAL. 2013. Diet and trophic structure of the fish fauna in a subtropical ecosystem: impoundment effects. Neotrop Ichthyol 11: 891-904.

FEIJOÓ CS \& LOMBARDO RJ. 2007. Baseline water quality and macrophyte assemblages in Pampean streams: a regional approach. Water Res 41: 1399-1410.

FEIJOÓ CS, GANTES P, GIORGI ADN, ROSSO JJ \& ZUNINO E. 2012. Valoración de la calidad de ribera en un arroyo pampeano y su relación con las comunidades de macrófitas y peces. Biol acuática 27: 113-128.

FERNÁNDEZ E, FERRIZ R, BENTOS C \& LÓPEZ G. 2012. Dieta y ecomorfología de la ictiofauna del arroyo Manantiales, 
provincia de Buenos Aires, Argentina. Rev del Mus Argentino Ciencias Nat n s 14: 1-13.

FERREIRA A, DE PAULA FR, DE BARROS FERRAZ SF, GERHARD P, KASHIWAQUI EA, CYRINO JEP \& MARTINELLI LA. 2012. Riparian coverage affects diets of characids in neotropical streams. Ecol Freshw Fish 21: 12-22.

FERREIRA-REZENDE C, MAZZONI R, PELLEGRINI-CARAMASCHI É, RODRIGUES D \& MORAES M. 2011. Prey selection by two benthic fish species in a Mato Grosso stream, Rio de Janeiro, Brazil. Rev Biol Trop 59: 1697-1706.

FIGUEIREDO BRS, MORMUL RP \& BENEDITO E. 2013. Nonadditive effects of macrophyte cover and turbidity on predator-prey interactions involving an invertivorous fish and different prey types. Hydrobiologia 716: 21-28.

FIGUEIREDO BRS, MORMUL RP \& BENEDITO E. 2015. Structural complexity and turbidity do not interact to influence predation rate and prey selectivity by a small visually feeding fish. Mar Freshw Res 66: 170-176.

FLETCHER DE, WILKINS SD, MCARTHUR JV \& MEFFE GK. 2000. Influence of riparian alteration on canopy coverage and macrophyte abundance in Southeastern USA blackwater streams. Ecol Eng 15: 67-78.

GABELLONE NA, CLAPS MC, SOLARI LC \& NESCHUK NC. 2005. Nutrients, conductivity and plankton in a landscape approach to a Pampean saline lowland river (Salado River, Argentina). Biogeochemistry 75: 455-477.

GERKING SD. 1994. Larval feeding. In: Gerking SD (Ed), Feeding ecology of fish, San Diego: Academia Press, p. 139-170.

GIORGI ADN, ROSSO JJ \& ZUNINO E. 2014. Efectos de la exclusión de ganado sobre la calidad ambiental de un arroyo pampeano. Biol Acuat 30: 133-140.

GRANITTO M, ROSSO JJ, BOVERI MB \& RENNELLA AM. 2016. Impacto del uso del suelo sobre la condición de ribera en arroyos pampeanos y su relación con la estructura de la comunidad de peces. Biol Acuat 31: 19-27.

GRETHER G, MILLIE D, BRYANT M, REZNICK D \& MAYEA W. 2001. Rain forest canopy cover, resource availability, and life history evolution in guppies. Ecology 82: 1546-1559.

HACUNDA JS. 1981. Trophic relationships among demersal fishes in a coastal area of the Gulf of Maine. Fish Bull 79: 775-788.

HUED AC \& BISTONI MÁ. 2005. Development and validation of a Biotic Index for evaluation of environmental quality in the central region of Argentina. Hydrobiologia 543: 279-298.
HYSLOP EJ. 1980. Stomach contents analysis-a review of methods and their application. J Fish Biol 17: 411-429.

KARR JR. 1981. Assessment of biotic integrity using fish communities. Fisheries 6: 21-27.

KARR JR, FAUSCH KD, ANGERMEIER PL, YANT PR \& SCHLOSSER IJ. 1986. Assessing biological integrity in running waters: a method and its rationale. Illinois: Illinois Natural History Survey, $31 \mathrm{p}$.

LAMMERT M \& ALLAN JD. 1999. Assessing biotic integrity of streams: effects of scale in measuring the influence of land use/cover and habitat structure on fish and Macroinvertebrates. Environ Manage 23: 257-270.

LAN D. 2017. La industria en Tandil. Datos generales del Relevamiento Industrial 2013. Tandil: Universidad Nacional del Centro de la Provincia de Buenos Aires, 43 p.

LEVINS R. 1968. Evolution in changing environments, some theoretical explorations. Monog Popul Biol 2: 1-120.

LÓPEZ CAZORLA AC, DURÁN W \& TEJERA L. 2003. Alimentación de la ictiofauna del río Sauce Grande, provincia de Buenos Aires, Argentina. Biol Acuat 20: 73-79.

LOPRETTO E \& TELL G. 1995. Ecosistemas de aguas continentales. Metodologías para su estudio. La Plata: Editorial Sur, 1401 p.

LOWE-MCCONNELL RH. 1987. Ecological studies in tropical fish communities. Cambridge: Cambridge University, 382 p.

LYONS J, WANG L \& SIMONSON TD. 1996. Development and validation of an index of biotic integrity for coldwater streams in Wisconsin. North Am J Fish Manag 16: 241-256. MAHIBBUR RM \& GOVINDARAJULU Z. 1997. A modification of the test of Shapiro and Wilks for normality. Journal of Applied Statistics 24: 219-235.

MANNA LR, REZENDE CF \& MAZZONI R. 2012. Plasticity in the diet of Astyanax taeniatus in a coastal stream from south-east Brazil. Brazilian J Biol 72: 919-928.

MARQUES PS, MANNA LR, MAZZONI R \& EL-SABAAWI R. 2019. Intraspecific trait variation in urban stream ecosystems: toward understanding the mechanisms shaping urban stream communities. Freshw Sci 38: 1-11.

MARTINS RT, COUCEIRO SR, MELO AS, MOREIRA MP \& HAMADA N. 2017. Effects of urbanization on stream benthic invertebrate communities in Central Amazon. Ecol Indic 73: 480-491.

MCCORMICK FH, HUGHES RM, KAUFMANN PR, PECK DV, STODDARD JL \& HERLIHY AT. 2001. Development of an index of biotic 
integrity for the Mid-Atlantic Highlands region. Trans Am Fish Soc 130: 857-877.

MELO CED, MACHADO FDA \& PINTO-SILVA V. 2004. Feeding habits of fish from a stream in the savanna of Central Brazil, Araguaia Basin. Neotrop Ichthyol 2: 37-44.

MILLS D \& VEVERS G. 1989. The Tetra encyclopedia of freshwater tropical aquarium fishes. New Jersey: Tetra Press, $208 \mathrm{p}$.

MOLINERO A \& FLOS R. 1991. Influence of sex and age on the feeding habits of the common sole Solea solea. Mar Biol 111: 493-501.

MONTAÑA CG, LAYMAN CA \& WINEMILLER KO. 2015. Speciesarea relationship within benthic habitat patches of a tropical floodplain river: an experimental test. Austral Ecol 40: 331-336.

MOSS B. 2008. Water pollution by agriculture. Philos Trans R Soc B Biol Sci 363: 659-666.

MUOTKA T, MÄKI-PETÄYS A, KREIVI P \& HOEGMANDER H. 1998. Spatial associations between lotic fish, macroinvertebrate prey and the stream habitat: a multiscale approach. Boreal Environ Res 3: 371-380.

NEEDHAM J \& NEEDHAM P. 1982. Guía para el estudio de los seres vivos de las aguas dulces. Barcelona: Reverté, $131 \mathrm{p}$.

NELSON DR \& MARLEY NJ. 2000. The biology and ecology of lotic Tardigrada. Freshw Biol 44: 93-108.

NEVES MP, DELARIVA RL \& WOLFF LL. 2015. Diet and ecomorphological relationships of an endemic, speciespoor fish assemblage in a stream in the Iguaçu National Park. Neotrop Ichthyol 13: 245-254.

O'CALLAGHAN P, KELLY-QUINN M, JENNINGS E, ANTUNES P, O'SULLIVAN M, FENTON O \& HUALLACHAIN DO. 2018. The environmental impact of cattle access to watercourses: A review. J Environ Qual 48: 340-351.

OPDS. 2009. Informe inédito dirigido al municipio de Tandil. Expediente 2436-10771/08. La Plata: OPDS.

ORICOLLI MCG \& BENNEMANN ST. 2006. Dieta de Bryconamericus iheringii (Ostariophysi: Characidae) em riachos da bacia do rio Tibagi, Estado do Paraná. Acta Sci Biol Sci 28: 59-63.

PARACAMPO A, MARROCHI N, GARCÍA I, MAIZTEGUI T, ARRIQUIRIBORDE P, BONETTO C \& MUGNI H. 2020. Fish Assemblages in Pampean Streams (Buenos Aires, Argentina): Relationship to Abiotic and Anthropic Variables. An Acad Bras Cienc 92: e20190476. https://doi. org/10.1590/0001-3765202020190476.
PAUL MJ \& MEYER JL. 2001. Streams in the urban landscape. Annu Rev Ecol Syst 32: 333-365.

PEDERSEN ER \& PERKINS MA. 1986. The use of benthic invertebrate data for evaluating impacts of urban runoff. Hydrobiologia 139: 13-22.

PERESSIN A, DA SILVA GONÇALVES C \& CETRA M. 2018. Ichthyofauna diet changes in response to urbanization: the case of upper Paranapanema River basin (Brazil). Urban Ecosyst 21: 795-803.

PIANKA ER. 1981. Competition and niche theory. In: May RM (Ed), Theoretical ecology, Oxford: Blackwell Scientific, p. 167-196.

PLATTS WS. 1979. Livestock grazing and riparian/stream ecosystems: An overview. Anim Stud Repos: 39-45.

POOLE GC. 2002. Fluvial landscape ecology: addressing uniqueness within the river discontinuum. Freshw Biol 47: 641-660.

RENNELLA AM, GERONAZZO MD, ROMERO ME, BOVERI M \& ROSSO JJ. 2019. Hydrological variability, zooplankton availability and the shift between planktivore-benthivore feeding behaviour in the visual predator fish, Odontesthes bonariensis. Environ Biol Fishes 102: 713-725.

Rosso JJ. 2006. Peces pampeanos: guía y ecología. Ciudad Autónoma de Buenos Aires: LOLA, 224 p.

ROSSO JJ \& FERNÁNDEZ CIRELLI A. 2013. Effects of land use on environmental conditions and macrophytes in prairie lotic ecosystems. Limnologica 43: 18-26.

ROSSO J \& QUIRÓS R. 2009. Interactive effects of abiotic, hydrological and anthropogenic factors on fish abundance and distribution in natural run-of-the-river shallow lakes. River Res Appl 25: 713-733.

ROUGHGARDEN J. 1974. Species packing and the competition function with illustrations from coral reef fish. Theor Popul Biol 5: 163-186.

RUIZ DE GALARRETA VA, BANDA NORIEGA RB, NAJLE R, RODRÍGUEZ C, BARRANQUERO R, DÍAZ A, MIGUEL R, PEREYRA M \& PRIANO M. 2013. Análisis de la calidad del agua del arroyo Langueyú, Tandil, Buenos Aires. Rev Est Amb 1: 2-26.

RUIZ DE GALARRETA VA, BANDA NORIEGA RB, BARRANQUERO RS, DÍAZ AA, RODRÍGUEZ CI \& MIGUEL RE. 2010. Análisis integral del sistema hídrico, uso y gestión. Cuenca del arroyo Langueyú, Tandil, Argentina. Bol Geol y Min 121: 343-356.

TENCATT LFC, DE BRITTO MR \& PAVANELLI CS. 2016. Revisionary study of the armored catfish Corydoras paleatus (Jenyns, 1842) (Siluriformes: Callichthyidae) over 180 years after its discovery by Darwin, with description of a new species. Neotrop Ichthyol 14: e150089. 
TÓFOLI RM, ALVES GHZ, HIGUTI J, CUNICO AM \& HAHN NS. 2013. Diet and feeding selectivity of a benthivorous fish in streams: responses to the effects of urbanization. J Fish Biol 83: 39-51.

UIEDA VS \& MOTTA RL. 2007. Trophic organization and food web structure of southeastern Brazilian streams: a review. Acta Limnol Bras 19: 15-30.

VIDON P, CAMPBELL MA \& GRAY M. 2008. Unrestricted cattle access to streams and water quality in till landscape of the Midwest. Agric Water Manag 95: 322-330.

VIGLIZZO EF, LÉRTORA F, PORDOMINGO AJ, BERNARDOS JN, ROBERTO ZE \& DEL VALLE H. 2001. Ecological lessons and applications from one century of low external-input farming in the pampas of Argentina. Agric Ecosyst Environ 83: 65-81.

VILCHES C. 2005. Comparison of producers' metabolism in Las Flores stream (Comparación del metabolismo en productores del arroyo Las Flores). Luján: National University of Luján, 83 p.

WALSH CJ, ROY AH, FEMINELLA JW, COTTINGHAM PD, GROFFMAN PM \& MORGAN RP. 2005. The urban stream syndrome: current knowledge and the search for a cure. J North Am Benthol Soc 24: 706-723.

WILLIS SC, WINEMILLER KO \& LOPEZ-FERNANDEZ H. 2005. Habitat structural complexity and morphological diversity of fish assemblages in a Neotropical floodplain river. Oecologia 142: 284-295.

WINEMILLER KO. 1989. Ontogenetic diet shifts and resource partitioning among piscivorous fishes in the Venezuelan llanos. Environ Biol Fishes 26: 177-199.

WINEMILLER KO, AGOSTINHO AA \& CARAMASCHI ÉP. 2008. Fish ecology in tropical streams. In: Dudgeon D (Ed), Tropical stream ecology, London: Academic Press, p. 107-146.

WOOTTON JT. 2012. River food web response to large-scale riparian zone manipulations. PLoS One 7: e51839.

WOOTTON RJ. 1999. Ecology of teleost fish. Dordrecht: Kluwer Academic Publishers, $404 \mathrm{p}$.

YOUNG DG \& DUNCAN MA. 1994. Guide to the identification and geographic distribution of Lutzomyia sand flies in Mexico, the West Indies, Central and South America (Diptera: Psychodidae). Gainesville: Associated Publishers, $881 \mathrm{p}$.

ZACCARELLI N, BOLNICK DI \& MANCINELLI G. 2013. RInSp: an $r$ package for the analysis of individual specialization in resource use. Methods in Ecology and Evolution 4: 1018-1023.

ZENI JO \& CASATTI L. 2014. The influence of habitat homogenization on the trophic structure of fish fauna in tropical streams. Hydrobiologia 726: 259-270.

\section{How to cite}

BERTORA A, FONTANARROSA MS, GROSMAN F, SANZANO P \& ROSSO JJ. 2021. Trophic ecology of the Neotropical tolerant fish Corydoras paleatus under the influence of contrasting environmental conditions in a prairie stream. An Acad Bras Cienc 93: e20200981. DOI 10.1590/00013765202120200981 .

Manuscript received on June 22, 2020;

accepted for publication on March 4, 2021

\section{ANDREA BERTORA ${ }^{1,2}$}

https://orcid.org/0000-0002-0466-4790

MARÍA S. FONTANARROSA ${ }^{1,2}$

https://orcid.org/0000-0002-1071-4942

\section{FABIÁN GROSMAN ${ }^{1}$}

https://orcid.org/0000-0002-9564-9691

\section{PABLO SANZANO 1}

https://orcid.org/0000-0002-4246-073X

\begin{abstract}
JUAN J. ROSSO 2,3
https://orcid.org/0000-0001-6730-9385

Correspondence to: Andrea Bertora

E-mail: bertorandrea@gmail.com
\end{abstract}

${ }^{1}$ Instituto Multidisciplinario sobre Ecosistemas y Desarrollo Sustentable (UNCPBA-CIC), Universidad Nacional del Centro de la Provincia de Buenos Aires, Pje. Arroyo Seco, s/n, Campus Universitario, Tandil, B7000, Buenos Aires, Argentina

${ }^{2}$ Consejo Nacional de Investigaciones Científicas y Técnicas (CONICET), Godoy Cruz 2290, Ciudad Autónoma de Buenos Aires, C1425FQB, Buenos Aires, Argentina

${ }^{3}$ Universidad Nacional de Mar del Plata, Grupo de Biotaxonomía Morfológica y Molecular de Peces, Instituto de Investigaciones Marinas y Costeras, Rodríguez Peña 4046, Mar del Plata, B7600, Buenos Aires, Argentina

\section{Author contributions}

$A B, M S F, F G, P S$ and JJR conceived and designed the investigation. $A B, F G, P S$ and JJR performed field work. AB and MSF performed laboratory work. AB, MSF and JJR analyzed the data. AB, MSF, FG, $\mathrm{PS}$ and JJR wrote the paper.

\section{(cc) BY}

